Article

\title{
Contraction of the Gobi Desert, 2000-2012
}

\section{Troy Sternberg *, Henri Rueff and Nick Middleton}

School of Geography, University of Oxford, South Parks Road, Oxford OX1 3QY, UK; E-Mails: henri.rueff@ouce.ox.ac.uk (H.R.); nicholas.middleton@ouce.ox.ac.uk (N.M.)

* Author to whom correspondence should be addressed; E-Mail: troy.sternberg@geog.ox.ac.uk; Tel.: +44-186-5285-070.

Academic Editors: Arnon Karnieli and Prasad S. Thenkabail

Received: 5 September 2014 / Accepted: 21 January 2015 / Published: 26 January 2015

\begin{abstract}
Deserts are critical environments because they cover $41 \%$ of the world's land surface and are home to 2 billion residents. As highly dynamic biomes desert expansion and contraction is influenced by climate and anthropogenic factors with variability being a key part of the desertification debate across dryland regions. Evaluating a major world desert, the Gobi in East Asia, with high resolution satellite data and the meteorologically-derived Aridity Index from 2000 to 2012 identified a recent contraction of the Gobi. The fluctuation in area, primarily driven by precipitation, is at odds with numerous reports of human-induced desertification in Mongolia and China. There are striking parallels between the vagueness in defining the Gobi and the imprecision and controversy surrounding the Sahara desert's southern boundary in the 1980s and 1990s. Improved boundary definition has implications for understanding desert "greening" and "browning", human action and land use, ecological productivity and changing climate parameters in the region. The Gobi's average area of 2.3 million $\mathrm{km}^{2}$ in the 21 st century places it behind only the Sahara and Arabian deserts in size.
\end{abstract}

Keywords: Gobi; desert boundary; expansion and contraction; Aridity Index; NDVI; Mongolia; China

\section{Introduction}

Deserts and semi-deserts are critical global environments that are commonly known as drylands. They cover $41 \%$ of the world's land surface and are home to 2 billion residents [1,2]. As the largest biome drylands support $44 \%$ of global agriculture, half the world's livestock and are significant for their 
biodiversity $[1,3,4]$. Drylands are highly dynamic environments that expand and contract due to natural drivers, particularly rainfall $[5,6]$. However, the global climate change literature is dominated by other ecosystems, particularly the humid tropics and polar regions. Rigorously measuring the size and establishing the boundaries for major world drylands is, therefore, a task of considerable importance, not least to produce baseline data and reference levels for assessments of desertification, carbon sequestration and ecosystem functioning [7-10].

Identification of desert regions and their extent has been imprecise due to fluctuating climate and environmental factors [6]. Since the 1970s, questions about desertification have received considerable policy attention and led to the United Nations Convention to Combat Desertification that defines desertification as "land degradation in arid, semi-arid, and dry subhumid areas resulting from various factors, including climatic variations and human activities" [4,11]. Concern over changes on the margins of the Sahara and the threat of desertification prompted investigation of desert boundaries with Tucker et al. [5] pioneering the use of remote sensing as a tool for measuring vegetation biomass. Continued research highlights the controversy, and often contradictory findings, that surround the desertification debate [7,12].

In China, the largest dryland country in Asia $\left(>4\right.$ million $\left.\mathrm{km}^{2}\right)$ [13], incomplete understanding about climate change in arid regions, transition ecotones and desert boundaries has resulted in uncertainty about dryland areas $[6,14,15]$. The Gobi, one of the world's largest deserts, was first named in 1706 yet today remains ill-defined [16,17]. Limited and localised research and little cross-border cooperation between China and Mongolia has contributed to a lack of data and poorly documented desert boundaries. Scientific literature lists the Gobi as c.1,300,000 square kilometres in extent (Table 1, [18-23]). However, assessment methods justifying the 1.3 million $\mathrm{km}^{2}$ figure are very rarely cited; boundaries and measurement methodology are neither verifiable nor repeatable. Recognition that the boundary on the south-eastern side of the Gobi is, like many desert boundaries, naturally dynamic [6] adds to the lack of precise estimates of the desert's extent. The vagueness in definition of the Gobi parallels the imprecision in defining the Sahara desert and the Sahel zone on its southern margin in the 1980s and 1990s and highlights the difficulties in identifying desertification $[5,12,15]$.

Table 1. Estimates of the Gobi desert area in English-language scientific literature.

\begin{tabular}{cccc}
\hline Source & Size $\left(\mathbf{m i l l i o n} \mathbf{~ k m}^{\mathbf{2}}\right)$ & Assessment Year & Methodology \\
\hline Cressy, 1960 [18] & 1.7 & none & None specified \\
NASA, 2011 [19] & 1.3 & none & None specified \\
Stoppato and Bini, 2003 [20] & 1.3 & none & None specified \\
Yu et al., 2004 [21] & $1.16-1.57$ & 2001 & NDVI 1982-1990 \\
Yu et al., 2004 [21] & 1.3 & none & None specified \\
Laurent et al., 2005 [22] & 1.3 & none & None specified \\
Dennell, 2012 [23] & 1.3 & none & None specified \\
\hline
\end{tabular}

Research, primarily in China, focuses on the risk and increase in desertification in the Gobi yet frequently fails to address climate variability or establish desert boundaries in the 21 st century $[7,22,24]$. Degradation estimates include 2 million $\mathrm{km}^{2}$ and $90 \%$ of the natural grasslands in China and $70 \%$ of Mongolia [24,25]. Further, there is a widespread understanding that desertification, signifying a relatively permanent change in land productivity in the area is primarily due to human impacts [26]. The 
process reflects the utilitarian or social value assigned to negative landscape changes [27]. This understanding has informed policy in the Gobi, particularly in Chinese grasslands. Recent large-scale anti-desertification projects include the "Pasture to Grassland" programme implemented in all of China's pastoral areas in 2003 and the "Control the source of Beijing and Tianjin Sandstorms" programme in Inner Mongolia [28]. One of China's most ambitious programmes to combat desertification and control dust storms, the "Three Norths Forest Shelterbelt" programme, began in 1978 and is not scheduled to be completed until 2050 [26].

However, not all agree about the extent or intensity of desertification in the Gobi or about the importance of the human impact. In a recent review, Wang et al. [7] concluded that there is surprisingly little unassailable evidence to support the claim that desertification in China is primarily due to human impacts. Indeed, received wisdom regarding anthropogenic drivers of desertification appears effectively to feedback on itself according to Cao et al. [29] who suggest that large-scale afforestation, a primary tool for controlling desertification and soil erosion in China, is actually exacerbating environmental degradation in some areas because it has been undertaken without adequate understanding of local climatic, pedological, hydrological and landscape factors. In a similar vein, Addison et al. [30] warn that many policies and programmes designed to address degradation on rangelands in Mongolia's Gobi desert are based on assumptions that are not supported all of the time. Studies of desertification and desert boundaries are undermined by a lack of clarity and definition across the Gobi region, which affects understanding of the impact of climate change, environmental processes and degradation with resultant implications for populations and governance.

There are multiple definitions of arid environments; all consider moisture balance and the relationship between precipitation and evapotranspiration [31]. Establishing the boundaries of a particular desert can be complicated by the use of localised names for areas within large deserts [32]. For example, Tucker et al. [5] included several sub-deserts in their assessment of the expansion and contraction of the Sahara. In the same way, we consider the Gobi to include contiguous desert areas in northern China: the Tengger, Ordos, Mu Us, Badain Jaran, Junggar, Gurbantunggut, Qubqi and Otindag [22,33,34]. Scientific identification of the dryland requires a thorough physical assessment; current remote sensing techniques enable systematic delineation of ecosystems. Using multiple tools the Gobi is here defined by data-driven documentation $[35,36]$. Clear demarcation of desert boundaries is needed before altered physical thresholds, such as identifying desertification, can be identified or claimed [7,37]. We propose a comprehensive delineation of the Gobi based on vegetation cover, aridity, precipitation data and topographic features.

\section{Methods}

\subsection{Study Area}

The Gobi Desert is a vast, mid-latitude dryland situated on the Mongolian plateau in East Asia. Global and regional climate regimes, continental location, elevation and temperature extremes $\left(-40{ }^{\circ} \mathrm{C}\right.$ to $\left.+40{ }^{\circ} \mathrm{C}\right)$ affect the Gobi's aridity and vegetation [38]. Precipitation variability, a short vegetation growth period and limited frost-free days produce significant fluctuations of desert boundaries and dryland cover from year to year [6,33]. This paper delineates the Gobi boundary based on (a) Normalized Difference 
Vegetation Index (NDVI) data from 2000 to 2012; (b) the 50 year composite Aridity Index (AI) data (1950-2000) and (c) topographic maps to identify area fluctuations. It then uses the Standard Precipitation Index (SPI), which monitors drought by assessing anomalous and extreme precipitation, to cross-check the NDVI data.

\subsection{Methods}

Vegetation reflects solar radiation in the near-infrared spectral region; NDVI is a widely used remotely sensed measurement of photosynthesizing vegetation to assess vegetal cover ranging from the maximum value 1 (dense vegetation) to the minimum value 0 (barren/sparse vegetation) [39]. The Moderate Resolution Imaging Spectroradiometer MODIS-Terra level 3 "Vegetation Indices" product was used to capture fluctuation in desert/arid (0.219) and semi-desert/semi-arid (0.323) zones of the Gobi [40] with a temporal resolution of 16 days and a 250m spatial area (product code MOD13Q1). The MODIS Reprojection Tool (v4.1 March 2009) was employed to determine detailed spatial resolution for the Gobi through Sinusoidal Projection [41]. Ground-truthing has shown the effectiveness of satellite assessment as an indicator of pasture conditions in the Gobi [36,42]. Prior fieldwork by the authors found NDVI results significantly correlated $(p \leq 0.01)$ with area vegetation line-transect data (basal coverage assessment, to 1-km) in the Gobi [43]. There are limitations in assessing a compact timespan in an arid landscape; however, this paper uses a longer temporal data set than employed in Tucker et al.'s [5] seminal work on desert areal extent.

In the region $>80 \%$ of precipitation occurs between May and September, corresponding with both the peak plant growth period and the short period of frost-free days (100-120 days) [38]. The link between NDVI-identified vegetation cover and precipitation is well-established [44]; here NDVI images were selected for August (29 August, MODQ13) from 2000 to 2012 to capture the maximum potential level of plant development and peak biomass. The composite NDVI data were then compared to CGIAR's Aridity Index map that is based on the 50-year annual average from 1950 to 2000 [35]. The aridity index (AI) is $\mathrm{AI}=\mathrm{MAP} / \mathrm{MAE}$ where MAP is the mean annual precipitation and MAE is the mean annual potential evapotranspiration [35]. Statistical analysis (Pearson Correlation) was used to identify if desert extent was significantly correlated with changes in the area of arid or semi-arid zones.

Topographical maps show a great altitudinal gradation from the desert ( $\sim 1500 \mathrm{~m}$ asl) to the northern Qilian Range of the Tibetan Plateau $(>5000 \mathrm{~m})$ which has been used to identify the southern boundary $[14,45,46]$. Unlike $\mathrm{Yu}$ et al. [21], we exclude the Taklamakan in our assessment because, although it is joined to the Gobi by a dryland corridor, the Taklamakan has a distinct topographical setting in the Tarim Basin which is separated by the Kuruktag Uplift from the Gobi [47]. A line from the Qilian Mountain-Kuruktag Uplift-Tien Shan Mountains demarcates the southwest boundary whilst the Tien Shan Mountains serves as the western border [39]. Elsewhere, in the absence of significant topographical barriers we use climatic/vegetation data to delineate desert extent. This process is similar to work done on vegetation gradients in the Sahara.

NDVI observations were then compared with precipitation data by examining the 3-month Standard Precipitation Index (SPI) drought record (June-August, 2000 to 2012) at 60 Gobi meteorological stations. Reflecting the standard deviation from the long-term mean at each station assessed, the SPI has been used to track drought in the Gobi Desert and has proved robust when compared to other indices 
(i.e., Palmer Drought Severity Index) [48,49]. Ranging from 3 to -3 , SPI values track the magnitude of precipitation divergence from the long-term norm (0); negative values indicate drier conditions with values below -1 documenting drought episodes [50]. Averaged summer SPI results covered the peak precipitation and vegetation growth period. Using $>30$ year precipitation records from the Chinese and Mongolian National Meteorological offices and the US National Oceanic and Atmospheric Administration (NOAA) drought was calculated to identify the relation of precipitation surplus/shortage to desert contraction and expansion represented by NDVI values. We hypothesized that a negative relation should occur whereby the lower the SPI value (indicating precipitation deficiency) the greater the extent of the Gobi.

\section{Results}

NDVI data show the contraction of the Gobi boundary from 2000 to 2012 (Figure 1). Precipitation-driven NDVI patterns identify a progressive decreasing trend in total desert area and a $544,000 \mathrm{~km}^{2}(18 \%)$ variance over the study period. Extent peaked at 2.52 million $\mathrm{km}^{2}$ in 2002 with a desert minimum of 2.08 million $\mathrm{km}^{2}$ in 2012, the most recent study year (Table 2) (Figure 1). The Gobi, as other deserts [6], experienced inter-annual fluctuation at its margins; more unusual was the declining trend in boundary area $\left(r^{2}=0.20\right)$ over the 13-year study period. Whilst 2012 's $12 \%$ decrease in area stresses the desert's contraction, a negative trend was also present prior to 2012. Further, there was greater variability in the internal arid zone than in the transitional semi-arid area. The NDVI's precipitation-driven vegetation scale suggests a 13-year average area of $2,354,460 \mathrm{~km}^{2}$; the Aridity Index presents a long-term 50-year average for the region of 2,229,000 $\mathrm{km}^{2}$. The contrasting methods provide similar total average area with measurements differing by $2 \%\left(55,460 \mathrm{~km}^{2}\right)$ (Figure 2).

Table 2. Desert area by arid and semi-arid zone, annual change in zone area from mean and from year to year and total desert area and change, based on NDVI data.

\begin{tabular}{|c|c|c|c|c|c|c|c|c|c|}
\hline \multirow{2}{*}{ Year } & Arid & Change (\%) & Change (\%) & \multirow{2}{*}{ Semi-Arid } & Change (\%) & Change (\%) & \multirow{2}{*}{ Total } & \multirow{2}{*}{$\begin{array}{l}\text { Change (\%) } \\
\text { year to year }\end{array}$} & \multirow{2}{*}{$\begin{array}{c}\text { Change }(\%) \\
\text { from mean } \\
\end{array}$} \\
\hline & $\mathbf{k m}^{2}$ & year to year & from mean & & year to year & from mean & & & \\
\hline 2000 & $1,797,132$ & -- & -0.7 & 560,109 & -- & 2.6 & $2,357,241$ & -- & 0.1 \\
\hline 2001 & $1,895,250$ & 5.5 & 4.6 & 556,225 & -0.7 & 1.9 & $2,451,475$ & 4.0 & 4.1 \\
\hline 2002 & $1,954,933$ & 3.1 & 7.5 & 567,829 & 2.1 & 3.9 & $2,522,761$ & 2.9 & 6.9 \\
\hline 2003 & $1,640,889$ & -16.1 & -10.2 & 588,290 & 3.6 & 7.3 & $2,229,179$ & -11.6 & -5.0 \\
\hline 2004 & $1,837,586$ & 12.0 & 1.6 & 567,578 & -3.5 & 3.9 & $2,405,165$ & 7.9 & 2.3 \\
\hline 2005 & $1,822,172$ & -0.8 & 0.7 & 496,516 & -12.5 & -9.9 & $2,318,688$ & -3.6 & -1.5 \\
\hline 2006 & $1,844,999$ & 1.3 & 2.0 & 529,526 & 6.6 & -3.0 & $2,374,524$ & 2.4 & 0.9 \\
\hline 2007 & $1,807,383$ & -2.0 & -0.1 & 622,040 & 17.5 & 12.3 & $2,429,423$ & 2.3 & 3.2 \\
\hline 2008 & $1,793,119$ & -0.8 & -0.9 & 506,806 & -18.5 & -7.6 & $2,299,925$ & -5.3 & -2.2 \\
\hline 2009 & $1,938,552$ & 8.1 & 6.7 & 527,022 & 4.0 & -3.5 & $2,465,575$ & 7.2 & 4.8 \\
\hline 2010 & $1,873,921$ & -3.3 & 3.5 & 529,672 & 0.5 & -3.0 & $2,403,593$ & -2.5 & 2.0 \\
\hline 2011 & $1,750,568$ & -6.6 & -3.3 & 517,749 & -2.3 & -5.4 & $2,268,316$ & -5.6 & -3.6 \\
\hline 2012 & $1,559,640$ & -10.9 & -16.0 & 522,473 & 0.9 & -4.4 & $2,082,113$ & -8.2 & -12.0 \\
\hline mean & $1,808,934$ & --- & --- & 545,526 & --- & --- & $2,354,460$ & --- & --- \\
\hline
\end{tabular}




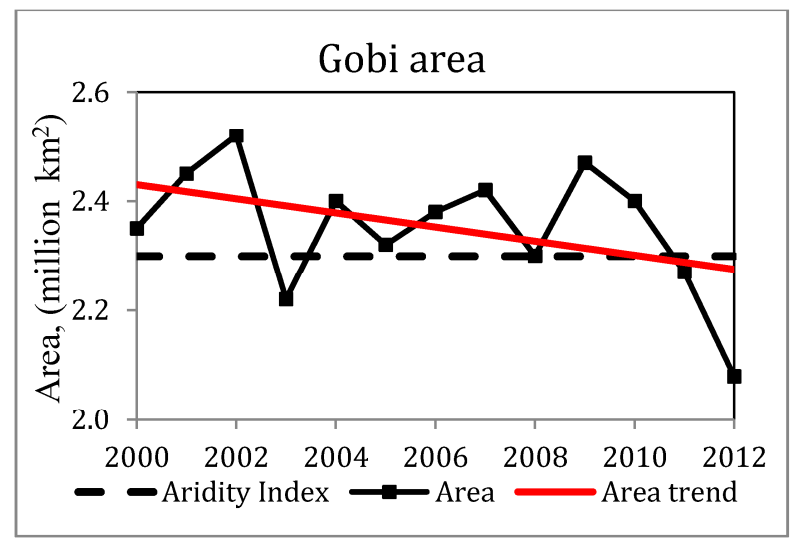

Figure 1. Total annual Normalized Difference Vegetation Index (NDVI) area of the Gobi with the Aridity Index and NDVI trendline.

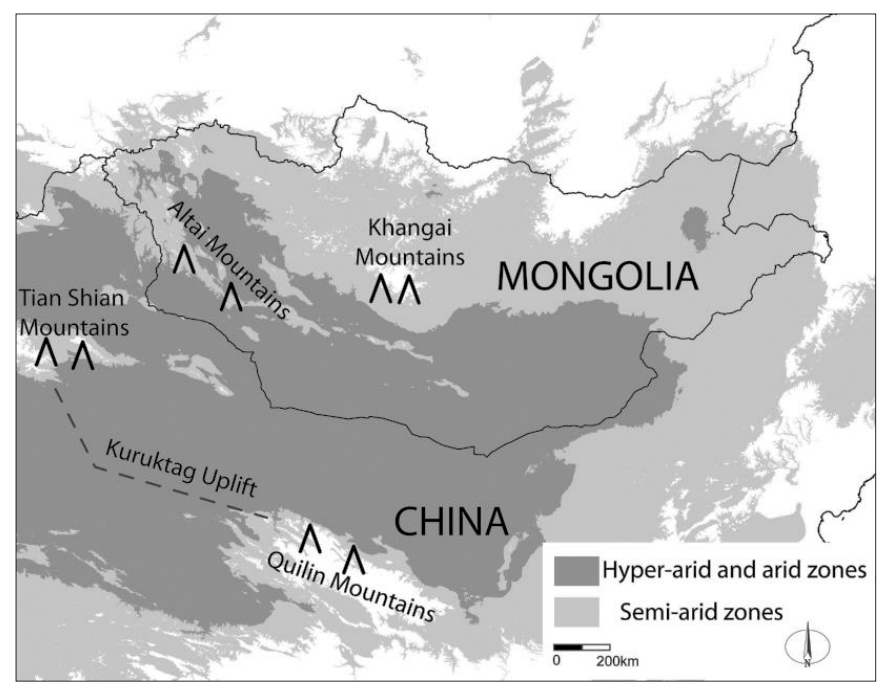

Figure 2. Map of the Gobi's arid (dark grey) and semi-arid (light grey) area identified by the Aridity Index, 1950-2000. Hyper-arid areas (limited in extent) are included in arid regions.

NDVI boundaries fluctuated approximately 5\% $\left(116,419 \mathrm{~km}^{2}\right)$ annually, reflecting year-to-year variability. This ranged from a 7.9\% increase (2004) to an $11.6 \%$ decrease in 2003. Patterns of expansion and contraction were not consistent between the arid and semi-arid sub-zones reflecting spatial instability between the two (Figure 3). Indeed, the largest decrease in both areas (arid 2003; semi-arid 2007) occurred in a year of increase in the other zone. The arid region drove desert fluctuation rather than in the semi-arid external border zone; only in 2005-2008 was the percentage of change in area greater in the semi-arid zone. Further, annual change in overall desert extent was significantly correlated with shifts in the arid area $(p<0.001)$ rather than the semi-arid zone.

Plotting the SPI 3 month drought record with NDVI data highlights the strong link between drought and desert extent; as drought levels increased vegetation cover decreased as expected $\left(r^{2}=0.49\right)$ (Figure 4). 2012 represented high moisture surplus (SPI $=+1$ ) across the Gobi and its minimum area. Further, the drought/dryness was strongly associated with change in the arid zone $\left(r^{2}=0.68\right)$ rather than the transitional semi-arid region $\left(r^{2}=0.07\right)$. Greater precipitation surplus was recorded in the western area whilst the northern Gobi (Mongolia) experienced the driest conditions with only two years above 
the 2000-2012 average. As with the shifting desert boundary, drought highlights regional climate variability typical of all drylands (as drought intensifies desert area increases) rather than establishing a "drying" of the Gobi desert as has been cited [51].

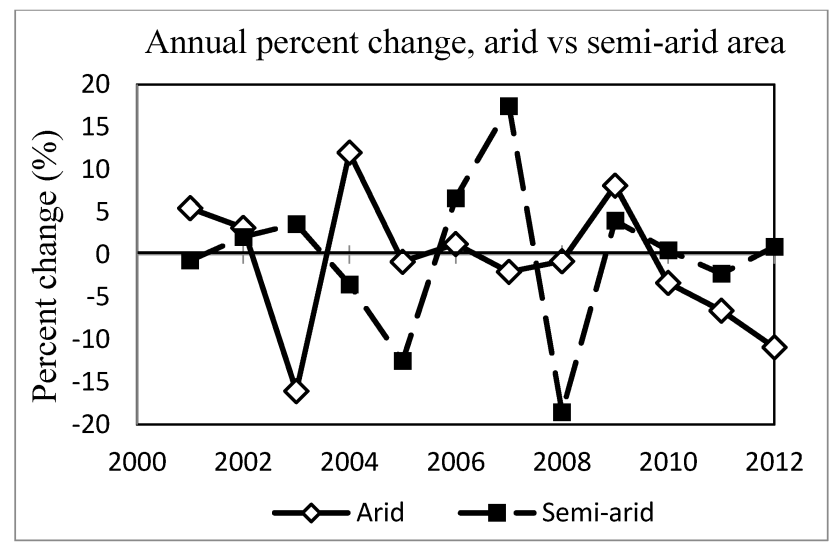

Figure 3. Annual area change from mean and from year to year, arid and semi-arid zones.

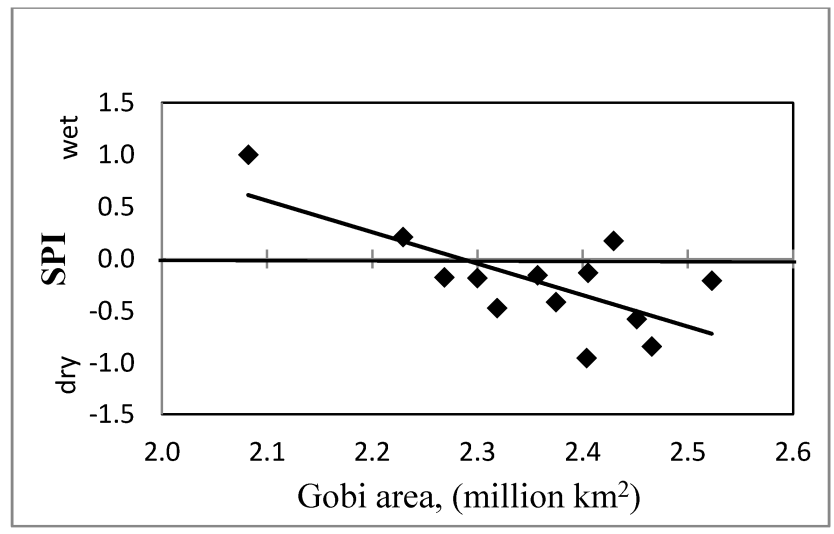

Figure 4. Relationship of the Standard Precipitation Index (SPI) drought record at meteorological stations $(n=60)$ with NDVI vegetation data; $r^{2}=0.49$. Below -1 identifies drought conditions.

Superimposed on an expected year-to-year variability is a decreasing trend in Gobi area. Because of fluctuation, demarcating desert boundaries is approximate rather than definitive. However, both NDVI data highlighting vegetation parameters and the Aridity Index stressing precipitation and potential evapotranspiration present a similar measurement of the region.

\section{Discussion}

This study identifies a contraction of the Gobi Desert from 2000 to 2012. Findings indicate a dry, expansionary period in the early 2000s (to 2.52 million $\mathrm{km}^{2}$ ) followed by a reduction in area that represent an $18 \%$ spatial variance over the study period. Within the desert the arid and semi-arid zones had markedly contrasting patterns in annual area increase/decrease. Boundary fluctuation over time mirrors Tucker et al.'s [5] assessment of the Sahara and similarly questions claims of the "total 
desertification area in China as 2.62 million $\mathrm{km}^{2}$ " [24]. We found the Gobi's decreasing trend differs from previous investigation in East Asia based on data from 1982 to 1990 [21].

The mixed quantitative methods used provide a measure of internal validation. The consistency of NDVI with the aridity index suggests that the study period was in line with the 50 year long-term average (see Section 3). Matching same-year SPI history with NDVI corroborated the implied moisture-based relationship between the two indices and encourages further work investigating drought and vegetation cover as related proxies in drylands. Identifying significant landform features, such as the Qilian Mountains and Kuruktag Uplift, integrated topography and prior scientific research to determine the Gobi's southern border [45,47]. The expansion and contraction of the Gobi echoes patterns recorded in the Sahara, Thar, Lut and other deserts [5,6]. The Gobi's spatial mapping more closely parallels the desert as portrayed by Meigs' (1953) [52] seminal work on deserts rather than Yu et al.'s 2004 effort that included parts of the Taklamakan Desert.

The precipitation-driven change in vegetation reflects the dominant climate patterns that affect East Asia. The central and southern Gobi experiences monsoonal climate variability that influences vegetation biomass [15]; the northern portion is strongly affected by the Siberian-Mongolian High pressure cell that contributes to cold and dry climatic conditions [53]. Factors such as El Niño events affect drought and flood patterns in northern China and have resulted in a $15 \%$ variance in regional agricultural harvests [54]. La Niña conditions also impact winter droughts in northern China where temperature differences and atmospheric pressure between the continent and Indo-Pacific Oceans affects the East Asian winter monsoon flow. Shifts in the Intertropical Convergence Zone, cold surges and warming in the Pacific contribute to weakened summer monsoons that can lead to drier conditions in East China [55,56]. Western areas of the Gobi are influenced by disturbances originating over the Mediterranean basin as well as by the east-Asian monsoon [16]. The effect of the continental climate and transitional monsoon boundary zone results in large precipitation variance as seen in this study [15]. This is reflected in the SPI-derived drought data and the inter-annual shifts in transition zones and desert area.

Our finding that the Gobi contracted from 2000 to 2012 due to increased moisture availability challenges much of the literature on desertification in the region and the widespread acceptance that desertification there is due primarily to human impacts [7,28,57], an understanding that has informed much policy in the Gobi, particularly in Chinese grasslands [58]. Government programmes in the Gobi have often been implemented with limited consideration of potential environmental constraints, an example being the late 20th century in-migration of millions of farmers to the Gobi despite limited water resources, a process resulting in noted degradation [59]. Similar efforts at state control are seen in China's major present-day programmes such as "Grain for Green”, "Ecological Resettlement”, “Great Green Wall" and "Control the source of the Beijing and Tianjin Sandstorms" that stress improving land conditions yet may have led to environmental deterioration $[28,29,60]$. NDVI may reflect an increase in degradation if it represents a decline in diversity or increase in unpalatable species whilst irrigation, deforestation, grazing and urbanisation have direct impact in the region [6]. Equally, a mining boom across the Gobi places environmental, water and development demands on the landscape [61].

We note striking parallels between the previous vagueness in definition of the Gobi and the imprecision in defining the Sahara desert that in the 1980s and 1990s was similarly bound up in controversy over desertification in the Sahel zone on its southern margin [5,21]. Spatial and temporal 
climate variability and severe drought in the Sahara and Sahel affected vegetation growth and perceived dryland extent in the 1980s [5]. However, a noted increase in rainfall in the early 1990s challenged the concept of the "advancing desert"; Nicholson et al. [62] found that no on-going change in Saharan boundaries had occurred. Our study identified parallel processes of ongoing climate variability and boundary fluctuation in the Gobi [63] projected impacts of global climate change suggest that climate variability will increase in the region. Reassessment of land cover in light of the declining trend in desert area suggests some claims of desertification might be more accurately regarded as part of the desert's natural fluctuation rather than a continued expansion [40,63]. Desert contraction questions whether land degradation has crossed a threshold to imply a new permanent state [4] or may reflect changing precipitation patterns and shifting desert boundaries. These issues are significant as the Gobi encompasses large agricultural regions and urban centres in China such as Baotou, Hohhot, Lanzhou, Urumqi ( $>2$ million people each), Ulaan Baatar, Mongolia (1.2 million people) and is positioned adjacent to Beijing (20 million residents). Our study provides a baseline for future research in the Gobi which is particularly important in this era of climate change and increasing human pressures.

\section{Conclusion}

Defining the spatial extent of the Gobi desert reduces uncertainty and imprecision surrounding the region. The Gobi is a vast dryland experiencing an extended period of contraction in area driven by rainfall; NDVI data indicates an average area of 2.3 million $\mathrm{km}^{2}$ in the 21 st century. Identifying the fluctuation in areal coverage, as well as a precise definition of the desert's extent, are important findings. Contemporary analysis at high NDVI resolution provides new documentation of spatial and temporal change and places the Gobi after the Sahara and Arabian Desert in extent [64]. Variability in both vegetation cover and internal desert zones encourages re-examination of the East Asian desertification debate. Improved boundary definition has implications for understanding desert "greening and "browning" [6], anthropogenic interaction, environmental productivity and changing climate parameters in this strategic area. Continued monitoring can further document the duration, extent and impact of the Gobi desert's contraction.

\section{Acknowledgements}

Research was supported by the British Academy, the Leverhulme Trust, the Royal Geographical Society's Thesiger-Oman International Desert Fellowship, the Swiss National Centre of Competence in Research (NCCR), North-South and the John Fell Research Fund, University of Oxford.

\section{Author Contributions}

Troy Sternberg conceived the idea, he and Nick Middleton devised the research plan. Henri Rueff did the remote sensing. All authors analyzed, interpreted and reviewed the data. Troy Sternberg drafted the manuscript, all authors discussed and revised the final manuscript. Nick Middleton and Henri Rueff contributed equally. 


\section{Conflicts of Interest}

The authors declare no conflict of interest.

\section{References}

1. Safriel, U.; Adeel, Z.; Niemeijer, D.; Puigfefabregas, J.; White, R.; Lal, R. Dryland systems. In Millennium Ecosystem Assessment: Ecosystems and Human Well-Being: Current State and Trends; El-Kassas, M., Ezcurra, E., Eds.; Island Press: Washington, DC, USA, 2005; pp. 623-662.

2. Food and Agriculture Organization of the United Nations (FAO). Water and Cereals in Drylands; Earthscan: London, UK, 2008.

3. Davies, J.; Poulsen, L.; Schulte-Herbrüggen, B.; Mackinnon, K.; Crawhall, N; Henwood, W.; Dudley, N.; Smith, J.; Gudka, M. Conserving Dryland Biodiversity; International Union for Conservation of Nature (IUCN): Nairobi, Kenya, 2012.

4. D’Odorico, P.; Bhattachan, A.; Davis, K.; Ravi, S.; Runyan, C. Global desertification: Drivers and feedbacks. Adv. Water Resour. 2013, 51, 326-344.

5. Tucker, C.; Dregne, H.; Newcomb, W. Expansion and contraction of the Sahara Desert from 1980 to 1990. Science 1991, 253, 299-301.

6. Jeong, S.; Ho, C.; Brown, M.; Kug, J.; Piao, S. Browning in desert boundaries in Asia in recent decades. J. Geophys. Res. 2011, doi:10.1029/2010JD014633.

7. Wang X, Chen, F.; Hasi, E.; Li, J. Desertification in China: An assessment. Earth-Sci. Rev. 2008, 88, 188-206.

8. Zhu, Z.; Sleeter, B.; Griffith, G.; Stackpoole, S.; Hawbaker, T.; Bergamaschi, B. An Assessment of Carbon Sequestration in Ecosystems of the Western United States-Scope, Methodology, and Geography; U.S. Geological Survey Professional Paper 1797; U.S. Geological Survey: Reston, VA, USA, 2012. Available online: http://pubs.usgs/gov/pp/1797 (accessed on 20 March 2014).

9. Poulter, B.; Frank, D.; Ciais, P.; Myneni, R.B.; Andela, N.; Bi, J.; Broquet, G.; Canadell, J.G.; Chevallier, F.; Liu, Y.Y.; et al. Contribution of semi-arid ecosystems to interannual variability of the global carbon cycle. Nature 2014, 509, 600-603.

10. Stoms, D.; Hargrove, W. Potential NDVI as a baseline for monitoring ecosystem functioning. Int. J. Remote Sens. 2000, 21, 401-407.

11. Reynolds, J.F.; Smith, D.M.S.; Lambin, E.F.; Turner, B.L., II; Mortimore, M.; Batterbury, S.P.J.; Downing, T.E.; Dowlatabadi, H.; Fernández, R.J.; Herrick, J.E.; et al. Global desertification: building a science for dryland development. Science 2007, 316, 847-851.

12. Thomas, D.; Middleton, N. Desertification: Exploding the Myth; Wiley: Chichester, UK, 1994.

13. Food and Agriculture Organization of the United Nations (FAO). Drylands, People and Land Use. 2009. Available online: fao.org/docrep/012/i0372e/i0372e01.pdf (accessed on 26 May 2014).

14. Shi, Y.; Shen, Y.; Kang, E.; Li, D.; Ding, Y.; Zhang, G.; Hu, R. Recent and future climate change in Northwest China. Clim. Chang. 2007, 80, 379-393.

15. Lu, W.; Jia, G. Fluctuation of farming-pastoral ecotone in association with changing East Asia monsoon climate. Clim. Chang. 2013, 119, 747-760. 
16. Von Wehrden, H.; Wesche, K. Relationships between climate, productivity and vegetation in southern Mongolian drylands. Basic Appl. Dryland Res. 2007, 1, 100-120.

17. Sternberg, T. Desert boundaries: The once and future Gobi. Geogr. J. 2014, doi:10.1111/geoj.12071.

18. Cressey, G. The Deserts of Asia; Syracuse University: Syracuse, NY, USA, 1960.

19. NASA. Dust storm in Gobi Desert, Mongolia. 2002. Available online: visibleearth.nasa.gov/ view.php?id=63315 (accessed on 23 January 2015).

20. Stoppato, M.; Bini, A. Deserts; Firefly Books: Toronto, ON, Canada, 2003.

21. Yu, F.; Price, K.; Ellis, J.; Feddema, J.; Shi, P. Interannual variations of the grassland boundaries bordering the eastern edges of the Gobi Desert in central Asia. Int. J Remote Sens. 2004, $25,327-343$.

22. Laurent, B.; Marticorena, B.; Bergametti, G.; Chazette, P.; Maignan, F.; Schmechtig, C. Simulation of the mineral dust emission frequencies from desert areas of China and Mongolia using an aerodynamic roughness length map derived from the POLDER. J. Geophys. Res. 2005, doi:10.1029/2004JD005013.

23. Dennell, R. Hominins, deserts, and the colonisation and settlement of continental Asia. Quatern. Int. 2012, 300, 13-21.

24. Yang, X.; Zhang, K.; Jia, B.; Ci, L. Desertification assessment in China: An overview. J. Arid Environ. 2005, 63, 517-531.

25. Regdel, D.; Dugarzhav, C.; Gunin, P. Ecological demands on socioeconomic development of Mongolia under climate aridization. Arid Ecosyst. 2012, 2, 1-10.

26. Wang, X.; Zhang, C.; Hasi, E.; Dong, Z. Has the Three Norths Forest Shelterbelt Program solved the desertification and duststorm problems in arid and semiarid China? J Arid Environ. 2010, $74,13-22$.

27. Eldridge, D.; Bowker, M.; Maestre, F.; Roger, E.; Reynolds, J.F.; Whitford, W.G. Impacts of shrub encroachment on ecosystem structure and functioning: Towards a global synthesis. Ecol. Lett. 2011, $14,709-722$.

28. Dalintai, B.; Yanbo, L.; Jianjun, C. The Eurasian Steppe: History of utilization and policies on the rangeland. In Restoring Community Connections to the Land; Fernandez-Gimenez, M.E., Wang, X., Baival, B., Klein, J., Reid, R., Eds.; CABI: Wallingford, UK, 2011; pp. 51-68.

29. Cao, S.; Chen, L.; Shankman, D.; Wang, C.; Wang, X.; Zhang, H. Excessive reliance on afforestation in China's arid and semi-arid regions: Lessons in ecological restoration. Earth-Sci. Rev. 2011, 104, 240-245.

30. Addison, J.; Friedel, M.; Brown, C.; Davies, J.; Waldron, S. A critical review of degradation assumptions applied to Mongolia's Gobi Desert. Rangel. J. 2012, 34,125-137.

31. Thomas, D. Arid Zone Geomorphology; Wiley-Blackwell: Chichester, UK, 2011.

32. Middleton, N. Deserts: A Very Short Introduction; Oxford University Press (OUP): Oxford, UK, 2009.

33. Goudie, A.; Middleton, N. Desert Dust in the Global System; Springer: Heidelberg, Germany, 2006.

34. Han, J.; Zhang, Y.; Wang, C.; Bai, W.; Wang, Y.; Han, G.; Li, L. Rangeland degradation and restoration management in China. Rangel. J. 2008, 30, 233-239. 
35. Trabucco, A.; Zomer, R. Global Aridity Index (Global-Aridity) and Global Potential Evapo-Transpiration (Global-PET) Geospatial Database, 2009. CGIAR Consortium for Spatial Information. Available online: www.csi.cgiar.org/ (accessed on 22 January 2013).

36. Karnieli, A.; Bayarjargal, Y.; Bayasgalan, M.; Mandakh, B.; Dugarjav, C.; Burgheimer, J.; Khudulmur, S.; Bazha, S.; Gunin, P. Do vegetation indices provide a reliable indication of vegetation degradation? A case study in the Mongolian pastures. Int. J. Remote Sens. 2013, $34,6243-6262$.

37. Shoshany, M. Identifying desert thresholds by mapping inverse erodibility and recovery potentials in patch patterns using spectral and morphological algorithms. Land Degrad. Dev. 2012, 23, 31-338.

38. Sternberg, T.; Thomas, D.; Middleton, N. Drought dynamics on the Mongolian steppe, 1970-2006. Int. J. Climatol. 2011, 31, 1823-1830.

39. Chen, Z.; Li, J.; Fang, K.; Davi, N.; He, X.; Cui, M.; Zhang, X.; Peng, J. Seasonal dynamics of vegetation over the past 100 years inferred from tree rings and climate in Hulunbei'er steppe, northern China. J. Arid. Environ. 2012, 83, 86-93.

40. Piao, S.; Fang, J.; Liu, H.; Zhu, B. NDVI-indicated decline in desertification in China in the past two decades. Geophys. Res. Lett. 2005, doi:10.1029/2004GL021764.

41. Earth Observing System Data and Information System. 2009. Available online: http:// www.echo.nasa.gov/reverb (accessed on 26 February 2014).

42. Tachiiri, K.; Shinoda, M.; Klinkenberg, B.; Morinaga, Y. Assessing Mongolian snow disaster risk using livestock and satellite data. J. Arid Environ. 2008, 72, 2251-2263.

43. Sternberg, T.; Tsolmon, R.; Middleton, N.; Thomas, D. Tracking desertification on the Mongolian steppe through NDVI and field-survey data. Int. J. Dig. Earth 2010, 1, 50-64.

44. Hao, F.; Zhang, X.; Ouyang, W.; Skidmore, A.; Toxopeus, A. Vegetation NDVI linked to temperature and precipitation in the upper catchments of Yellow River. Environ. Model. Assess. 2012, 17, 389-398.

45. Jolivet, M.; Brunel, M.; Seward, D.; Xu, Z.; Yang, J.; Roger, F.; Tapponnier, P.; Malavieille, J.; Arnaud, N.; Wu, C. Mesozoic and Cenozoic tectonics of the northern edge of the Tibetan plateau: Fission-track constraints. Tectonophysics 2001, 34, 111-134.

46. Zhang, B.; Tsunekawa, A.; Tsuboa, M. Contributions of sandy lands and stony deserts to long-distance dust emission in China and Mongolia during 2000-2006. Glob. Planet Chang. 2008, $60,487-504$.

47. Wang, Q.; Nishidai, T.; Coward, M. The Tarim basin, NW China: Formation and aspects of petroleum geology. J. Petrol. Geol. 1992, 15, 5-34.

48. Keyantash, J.; Dracup, J. The quantification of drought: An analysis of drought indices. Bull. Am. Meteorol. Soc. 2002, 83, 1167-1180.

49. Sternberg, T.; Middleton, N.; Thomas, D. Pressurised pastoralism in South Gobi, Mongolia: what is the role of drought? Trans. Inst. Br. Geogr. 2009, 34, 364-377.

50. Hayes, M.; Svoboda, M.; Wilhite, D.; Vanyarkho. Monitoring the 1996 drought using the standardized precipitation index. Bull. Am. Meteorol. Soc. 1999, 80, 429-438. 
51. Myoung, B.; Choi, Y.; Choi, S.; Park, S. Impact of vegetation on land-atmosphere coupling strength and its implication for desertification mitigation over East Asia. J. Geophys. Res. 2012, doi:10.1029/2011JD017143.

52. Meigs, P. World Distribution of Arid and Semi-Arid Homoclimates; United Nations: Paris, France, 1953.

53. Rudaya, N.; Li, H.C. A new approach for reconstruction of the Holocene climate in the Mongolian Altai: The high-resolution $\delta{ }^{13} \mathrm{C}$ records of TOC and pollen complexes in Hoton-Nur Lake sediments. J. Asian Earth Sci. 2013, 69, 185-195.

54. Tao, F.; Zhang, Z.; Yokozawa, M. Dangerous levels of climate change for agricultural production in China. Reg. Environ. Chang. 2011, 11, 41-48.

55. Dai A. Drought under global warming: A review. WIREs Clim. Chang. 2011, 2, 45-65.

56. She, D.; Xia, J. The spatial and temporal analysis of dry spells in the Yellow River basin, China. Stoch. Environ. Res. Risk Assess. 2012, 27, 29-42.

57. Ren, H.; Shen, W.; Lu, H.; Wen, Y.; Jian, S. Degraded ecosystems in China: Status, causes and restoration efforts. Landsc. Ecol. Eng. 2010, 3, 1-13.

58. Wang, F.; Pan, X.; Wang, D.; Shen, C.; Lu, Q. Combating desertification in China: Past, present and future. Land Use Policy 2013, 31, 311-313.

59. Zhang, M.; Borjigin, E.; Zhang, H. Mongolian nomadic culture and ecological culture: On the ecological reconstruction in the agro-pastoral mosaic zone in Northern China. Ecol. Econ. 2007, $62,19-26$.

60. Huang, L.; Xiao, T.; Zhao, Z.; Sun, C.; Liu, J.; Shao, Q.; Wang, J. Effects of grassland restoration programs on ecosystems in arid and semiarid China. J. Environ. Manag. 2013, 117, 268-275.

61. Reeves, J. Resources, sovereignty, and governance: Can Mongolia avoid the "resource curse"? Asian J. Pol. Sci. 2011, 19, 170-185.

62. Nicholson, S.; Tucker, C.; Ba, M. Desertification, drought, and surface vegetation: An example from the West African Sahel. Bull. Am. Meteorol. Soc. 1998, 79, 815-829.

63. Von Wehrden, H.; Hanspach, J.; Ronnenberg, K.; Wesche, K. Inter-annual rainfall variability in Central Asia-A contribution to the discussion on the importance of environmental stochasticity in drylands. J Arid Environ. 2010 74, 1212-1215.

64. Laity, J. Deserts and Desert Environments; Wiley-Blackwell: Chichester, UK, 2008.

(C) 2015 by the authors; licensee MDPI, Basel, Switzerland. This article is an open access article distributed under the terms and conditions of the Creative Commons Attribution license (http://creativecommons.org/licenses/by/4.0/). 